\title{
Correction to: Climate Governance and Finance in Bangladesh
}

\author{
Mousumi Pervin, Pulak Barua, Nuzhat Imam, Md. Mahfuzul Haque \\ and Nahrin Jannat Hossain
}

\section{Correction to:}

Chapter 6 in: S. Huq et al. (eds.), Confronting Climate Change in Bangladesh, The Anthropocene: Politik-Economics-Society-Science 28, https://doi.org/10.1007/978-3-030-05237-9_6

In the original version of the book, the following belated corrections have been incorporated:

In chapter "Climate Governance and Finance in Bangladesh", the chapter author affiliations has been updated to

4. Md. Mahfuzul Haque: Transparency International Bangladesh, Dhaka, Bangladesh

5. Nahrin Jannat Hossain: Jagannath University, Dhaka, Bangladesh. 